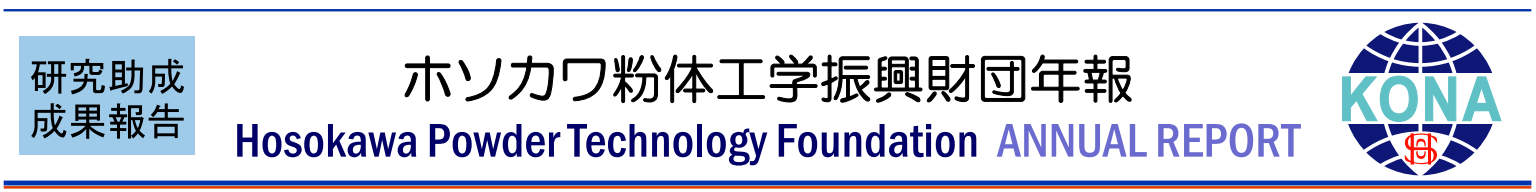

16112

\title{
環境応答性ヒドロゲル微粒子の非対称化 \\ Preparation of Anisotropic Stimulus-Responsive Hydrogel Microspheres
}

\author{
研究代表者 Research leader：鈴木 大介 Daisuke SUZUKI \\ 信州大学大学院繊維学系 准教授 \\ Graduate School of Science and Technology, Shinshu University, Associate Professor \\ E-mail: d_suzuki@shinshu-u.ac.jp
}

抄 録

水中で高度に膨潤し, 環境変化に応答して性質を変化できるヒドロゲル微粒子は, センサーや化粧 品, ドラッグキャリアーとしての応用が期待されている。これまでに多くの機能性ヒドロゲル微粒 子が報告されてきたが, 一般的にゲル微粒子の構造や相互作用部位は等方的であり, 非対称性構造 を有するヒドロゲル微粒子の合成は難しいと考えられてきた。ゲル微粒子の秀でた性質に加え, 非 対称構造をゲル微粒子に導入することができれば，上述した現存の応用分野のみならず，例えば生 体物質のモデル化など, 次世代科学技術の発展においてその影響は大きいと考えられる.そこで我々 は, 上記目的達成のため, 等方構造を有するゲル微粒子とは一線を画した非対称型ゲル微粒子を提 案する。

\section{ABSTRACT}

Water-swollen hydrogel microspheres, microgels, are expected to be useful in various applications including coating, sensor, and carrier of drug delivery system. Until now, various types of functional microgels, such as core-shell microgels and hollow microgels, have been reported, anisotropic microgels, whose physicochemical structures are not homogeneous, remains to be studied. Therefore, in this study, our group tried to prepare such new types of hydrogel microspheres by modification of homogeneous polymeric microspheres at the interfaces.

\section{研究背景と目的}

水中で高度に膨潤し，温度や $\mathrm{pH}$ などの外部 環境の変化に応答して性質を自在に変化させる ことが可能なヒドロゲル微粒子は, 表示材料や 化粧品, センサー, 乳化剂, DDSキャリアー をはじめとする, 多くの分野での応用が期待さ
れる。 ヒドロゲル微粒子は, 水中における沈殿 重合により，1986 年に初めてその合成例が報 告されて以来 ${ }^{[1]}$, 多くの刺激応答性ゲル微粒子 の報告がなされてきた。沈殿重合は, 重合初期 に生成したグロビュールポリマー間の会合によ り生じる粒子核に，新たに形成したグロビュー ルポリマーが吸着・積層することで粒子形成が 
促進される，その際，基本的には，疎水的なグ ロビュール化ポリマーは, 水中で個々の界面積 を最小にするために, 熱力学的な制約を受けて 真球状の構造を形成する。そのため, 微粒子の 中心部から段階的に化学的性質が変化するコア シェル構造や中空構造を有する機能性ゲル微粒 子が誕生してきた ${ }^{[2]}$. 実際に, 報告されてきた ヒドロゲル微粒子のほとんどが, そのような構 造を有しているものである。一方，上述したよ うな合成手法の制約上，非球形やヤヌス型など をはじめとする, 非対称構造を有するヒドロゲ 儿微粒子の報告例は極めて限られていた. 既に, ポリスチレンやシリカ微粒子をはじめとする硬 質微粒子を活用した微粒子非対称化に関する研 究において, 非対称型微粒子が, 均一構造を有 する微粒子だけでは成し得ない微粒子集積体を 形成することが確認されてきた。したがって, 優れた水中に扔ける分散安定性や, 迅速な刺激 応答性を有するヒドロゲル微粒子に対して, 硬 質微粒子に対してなされてきたような非対称構 造の導入が可能となれば，ヒドロゲル微粒子の 多様な応用分野の発展のみならず，微粒子材料 を応用した新たな分野の創出に繋がることが期 待される。

そこで本研究では, 真球で, 均一な性質を有 するヒドロゲル微粒子に対して, 非対称的な性 質を付与したゲル微粒子を作製し，その性質の 調査を実施した。

\section{研 究 方 法}

様々なサイズ・架橋度・官能基を有するヒド ロゲル微粒子をソープフリー水系沈殿重合法に よって合成した，得られたゲル微粒子は精製後, 任意の濃度に調節し, 界面に抢ける吸着性を水 滴の形成における界面吸着性を評価する事で調 べた。また, 各種油を混合し, 超音波ホモジナ イザーを照射する事によりピッカリングエマル ションを形成した。 この時, ヒドロゲル微粒子 単体だけでなく，ヒドロゲル微粒子に対して固 体成分を複合化させたナノコンポジットゲル微
粒子を適用し, 複合構造が与える影響を調べた

以上の検討結果を踏まえ, 続いて界面に吸着 したヒドロゲル微粒子に対して, 修飾反応を実 施した。例えば，負に帯電したミクロンサイズ ゲル微粒子を用いて作製したエマルションに対 して，反対符号の電荷を表面に有したコアシェ ル型ゲル微粒子を吸着させることで非対称化を 実施した。

\section{研 究成 果}

\section{様々な性質を有するヒドロゲル微粒子の作製}

界面に抢けるゲル微粒子に非対称化を考えた 際, 通常の硬質微粒子とは異なり, 柔らかいゲ ル微粒子は変形の影響を考慮する必要性があっ た、そこでまず，様々なサイズ・架橋度を有す るヒドロゲル微粒子を合成し, 界面上における ヒドロゲル微粒子の変形の調查を実施した。一 般に, 水膨潤状態のサブミクロンサイズのヒド ロゲル微粒子を, 解像度が高い状態で可視化す る事は難しい，本研究においても，サブミクロ ンサイズのゲル微粒子一粒を視認するのが精 いっぱいであり, ゲル微粒子の変形までを確認 する事は困難であった。そこで，ゲル微粒子の 大粒子径化を実現するため, シード沈殿重合法 ${ }^{[3]}$ を拡張し, 独自に開発した温度制御一モノマー フィード法 ${ }^{[4]}$ を駆使した。 得られたゲル微粒 子の光学顕微鏡画像の一例を図 1 に示す、いず れも単分散であり, 粒子径は $1.3 \mu \mathrm{m}(\mathrm{CV}=8 \%)$ であった（図 1(a)）。また，GMAのエポキシ基 の改質反応を経て, ゲル微粒子内にスルホン基 を有するMPSAを導入すると粒子径は $2.4 \mu \mathrm{m}$ $(\mathrm{CV}=4 \%)$ まで増大した（図 1(b)）。これは導 入されたMPSAのスルホン基に由来する浸透 圧および静電反発の効果と考えられる。また, 得られたゲル微粒子の表面電荷を評価するため に, 電気泳動を実施したところ, 絶対值の大き な負の值を示した．ゲル微粒子は高分子の密度 が低く, 光学顕微鏡によって可視化する事が困 難であった，そこで，ゲル微粒子が有する負電 荷に対して, カチオン性染料を静電気的に吸着 

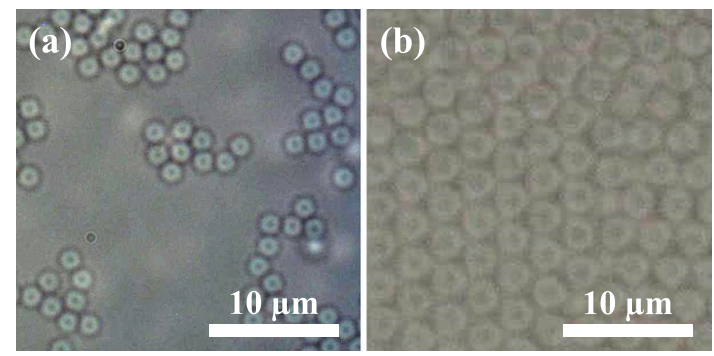

Fig. 1 Optical microscope images of each microgel observed at interfaces. (a) before chemical modification, and (b) after chemical modification of hydrogel microspheres studied in this project.

させた。すると,界面上に拐いて大きく変形し， ゲル微粒子同士が接触し合った状況を初めて確 認する事に成功した。やはり予想通り，ゲル微 粒子は界面上において大きく変形し, 硬質微粒 子のように球形を維持していない事が分かっ た。この事が, 界面上に打ける非刘称化を難し くする大きな要因であると考えた.

\section{ナノコンポジットゲル微粒子の界面における 挙動の調查}

上述したように, 柔らかいヒドロゲル微粒子 は界面において大きく変形してしまうため, 球 形を維持したまま非対称化をする事が困難であ ることが明確となった，そこで，独自技術 ${ }^{[5]}$ でヒドロゲル微粒子内に硬質成分を複合化した 新規ゲル微粒子(ナノコンポジットゲル微粒子) を用い，この界面挙動の調査を実施した。例え ば, ヘキサデカンを油相に選択した Pickering emulsionの作成を試みたところ，通常のゲル微 粒子と同様にナノコンポジットゲル微粒子は乳 化剂として機能した。一般に, 親水性の高いゲ ル微粒子はエマルションの型を反転させること ができない.しかし，本ナノコンポジットゲル 微粒子では, 多様な油において, エマルション の型を制御する事を見出した。この事は, ナノ コンポジットゲル微粒子が水油界面に抒いて, その位置をナノスケールで制御されている可能 性がある事を示唆している. 続く検討において, より精密なゲル微粒子の非対称化が実現される 可能性があると考えている。

\section{ゲル微粒子の非対称化}

様々なゲル微粒子安定化エマルションを得る ために, 粒子濃度, 水油混合比, 擋拌速度など の諸条件を検討した。このエマルションは温度 などの外的刺激を与えぬ限り, 一か月以上安定 であった，続いて，このエマルションに対し， 正電荷を帯びたゲル微粒子を複合化させた。こ の時には, 塩濃度の調整が複合化の鍵を握った。 即ち, 塩濃度を調節せずに複合化した場合, エ マルションは目視で確認できるほど粗大な凝集 塊を形成し, 沈殿した（図2(1)）。これは, 負 に带電したエマルションと, 添加した正電荷ゲ ル微粒子間に働く静電引力により, 橋かけ凝集 が形成したためと考えられる。そこで, 混合時 に $\mathrm{NaCl}$ を添加し, 微粒子間に働く静電引力を 調整したところ, 安定に分散した混合溶液を得 た (図 2(4,5))。続いて, 得られたエマルショ ンを光学顕微鏡により観察した. エマルション 界面に固定化された負に帯電したゲル微粒子表
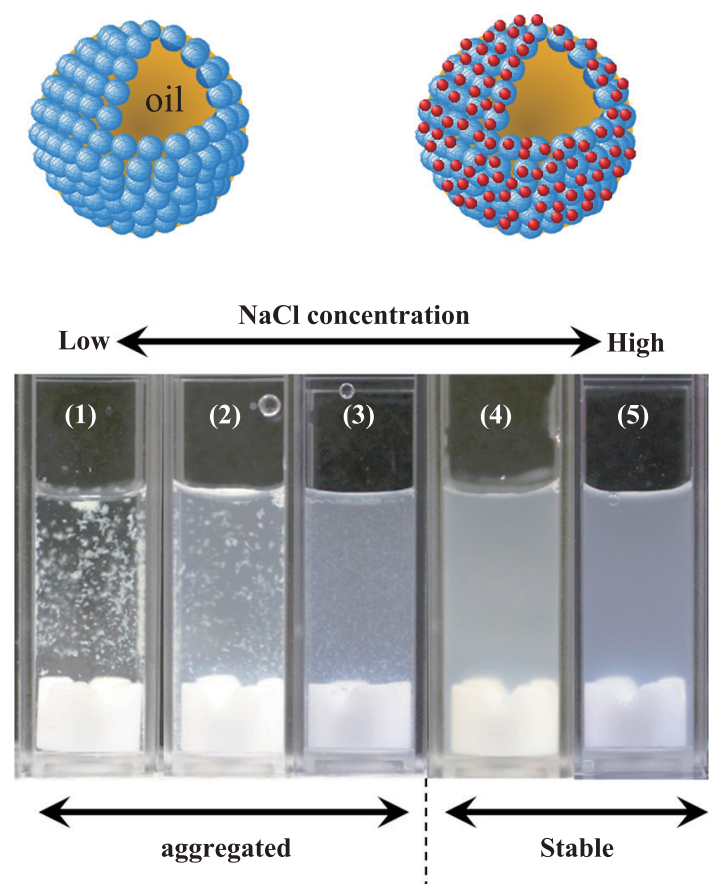

Fig. 2 Optical microscope images of hybrid emulsions stabilized by hydrogel microspheres. Photographs of the emulsions prepared at different $\mathrm{NaCl}$ concentration; (1) $0 \mathrm{mM}$, (2) $10 \mathrm{mM}$, (3) $300 \mathrm{mM}$, (4) $350 \mathrm{mM}$, and (5) $400 \mathrm{mM}$. 
面に正電荷ゲル微粒子が吸着した複合構造を確 認した。目的の構造を有する非対称化ヒドロゲ ル微粒子を確認する事はできたが，分散安定性 の点において問題が残った。この問題点を解決 するために，用いるゲル微粒子の種類・エマル ションの状態・複合化手法などを網羅的に検討 したが，高い水準での非対称化の達成には，ま だ時間を要すると考えている。

解決するための一手法として, 我々は, 重合 法に立ち返り，後処理なしで非対称構造を有し たヒドロゲル微粒子の創製にも取り組みはじめ た。挑戦的な課題ではあるが，各種ゲル微粒子 の評価手法を駆使する事で, 単分散な非対称化 ヒドロゲル微粒子が得られる兆しが見え始めて いる.

\section{外部発表成果}

\section{論文発表}

1. Minato H., Murai M., Watanabe T., Matsui S., Takizawa M., Kureha T., Suzuki D., The deformation of hydrogel microspheres at the air/water interface, Chemical Communications, 54 (2018) 932-935. DOI: 10.1039/C7CC09603H

2. Takizawa M., Sazuka Y., Horigome K., Sakurai Y., Matsui S., Minato H., Kureha T., Suzuki D., Self-organization of soft hydrogel microspheres during the evaporation of aqueous droplets, Langmuir, 34 (2018) 4515-4525. DOI: 10.1021/ acs.langmuir. $8 \mathrm{~b} 00230$

\section{学会発表}

1. 鈴木大介, 滝沢 優哉, 佐塚友茄, 堀达幸司, 櫻井 祐貴, 湊 遥香, “ソフトゲル微粒子分 散液の乾燥に伴う自己組織化”，第 68 回コ ロイドおよび界面化学討論会, 神戸大学（兵

\section{参考文献}

[1] Pelton R.H., Chibante P., Preparation of aqueous latices with $\mathrm{N}$-isopropylacrylamide, colloids and surfaces, 20 (1986) 247-256. DOI: 10.1016/0166-6622(86)80274-8

[2] Suzuki D., Horigome K., Kureha T., Matsui S., Watanabe T., Polymeric hydrogel microspheres: design, synthesis, characterization, assembly and applications, Polymer Journal, 49 (2017) 695-702. DOI: 10.1038/pj.2017.39

[3] Jones C.D., Lyon L.A., Synthesis and characterization of multiresponsive core-shell microgels, Macromolecules, 33 (2000) 8301-8306. DOI: 10.1021/ma001398m

[4] 鈴木 大介, 湊 遥香, 大浦 舜, ゲル微粒子の製造 方法, 特開 2018-048298, 公開日 3 月 29 日（2018）

[5] Suzuki D., Kobayashi C., Raspberry-shaped composite microgel synthesis by seeded emulsion polymerization with hydrogel particles, Langmuir, 30 (2014) 70857092. DOI: 10.1021/1a5017752

庫，2017 年 9 月 6 日）口頭（1A37）。

2. 湊遥香, 渡邊 拓巳, 鈴木 大介, “温度制御 ノフィード沈殿重合法による巨大ハイドロ ゲル微粒子の創製と界面におけるゲル微粒 子の変形挙動の評価”，第 29 回高分子ゲル 研究討論会, 東京工業大学 (東京, 2018 年 1月 11 日） 口頭（3).

3. 滝沢 優哉, 湊 遥香, 鈴木 大介, “八イドロ ゲル微粒子の気水界面における吸着挙動と 応用”, 第 69 回コロイドおよび界面化学討 論会, 筑波大学（茨城，2018 年 9 月 18 日） 口頭 (1E37).

4. 渡邊拓巳, Jiang Hang, To Ngai, 鈴木大介, “ナノコンポジットゲル微粒子を乳化剂とし たエマルション”，第 69 回コロイドおよび 界面化学討論会, 筑波大学（茨城，2018 年 9 月 18 日） 口頭（1E39）.

5. Suzuki D., Takizawa M., Minato H., Sazuka Y., "Functional hydrogel microspheres at the air/ water interface", 255th ACS National Meeting (New Orleans, America, March $21^{\text {st }}$ ) Oral (POLY 686), Invited lecture. 